\title{
A Study of Pungency of Capsaicinoid as Affected by Their Molecular Structure Alteration
}

\author{
Junlian Wang ${ }^{1}$, Zhenghong Peng ${ }^{2}$, Shengze Zhou ${ }^{3}$, Jinxi Zhang ${ }^{4}$, Songfei Zhang', Xiangfeng Zhou ${ }^{5}$, \\ Xiaobin Zhang ${ }^{1}$, Bixian Peng ${ }^{6 *}$
}

\begin{abstract}
${ }^{1}$ Department of Material Science and Engineering, Zhejiang University, Hangzhou, China; ${ }^{2}$ Chemistry Laboratory, M. D. Anderson Cancer Center, Texas University, Houston, USA; ${ }^{3}$ Department of Pure and Applied Chemistry, University of Strachclyde, Glasgow, England; ${ }^{4}$ Beijing Tiangonglongyuan Int'l Bio-Science \& Technology Company Ltd., Beijing, China; ${ }^{5}$ Beijing Jiuzhoulongling Hi-Tech Env. Prot. Mat. Company, Beijing, China; ${ }^{6}$ Technical Institute of Physics and Chemistry, CAS, Beijing, China.

Email: *pengbx@mail.ipc.ac.cn
\end{abstract}

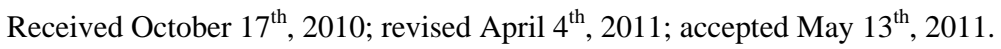

\begin{abstract}
An attempt was made in an effort to synthesize a series of capsaicinoids, most of which are synthesized in our laboratory and characterized to be completely new members of capsaicinoids. The Structure-pungency dependence are presented and discussed.
\end{abstract}

Keywords: Capsaicinoid, Preparation, Structure, Pungency

\section{Introduction}

The research of capsaicinoid used in medical treatment of various diseases has been attracting the attention of medical scientists from various countries for many years running. Bates T. E. et al. [1]. showed that capsaicin has a remarkable effect, simultaneously with the morphological.

Alteration of lung caner cells, to cause lung cancer cell's fading and necrosis. American and Japanese scientists [2] reported capsaicin to be affectuated to kill the most human's prostate gland's cancer cells. In addition capsaicin has been shown to be of medical treatment activities, Such as anticoagulation of blood platelet [3], adjustment (regulation) of metabolite stimulation of Chemical carcinogenic substances [4], restraining the growth of transforming cell like Hela, Ovary malignant tumour, mammary gland.

Malignant tumour and human promyelocytic lukemia cells [5]. The induced antiproliferative effect through a mechanism facilitated by ER stress in prostate PC-3 cells [6], induced expression of androgen receptor via PI3k MAPK pathways in prostate LNCaP cells [7], prostate cancer cells' suppressor [8], induced apoptosis of prostate PC-3 cells [9], displayed anti-proliferative activity against human small cell lung cancer in cell culture [10] and the induced apoptosis in leukemic cells through oxi dative stress [11]. The above accumulating evidence sup-

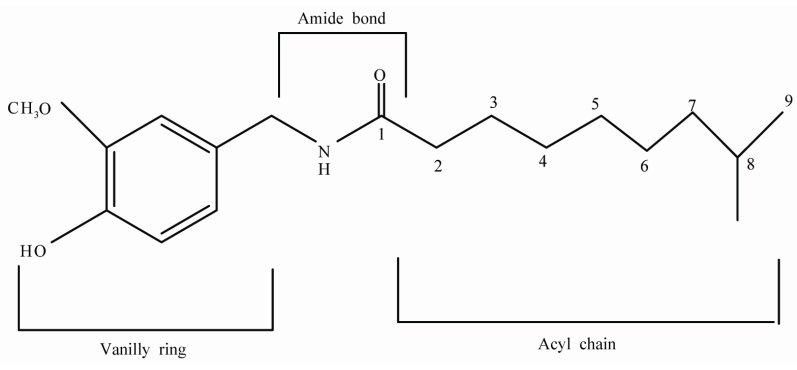

Figure 1. Essentical structural characteristics of capsaicin which determine its pungency.

ports the notion that capsaicin exhibits antimutagenic, anticarcinogenic and antioxidant activities in many cell types and conditions and therefore sustained efforts are made to understand the molecular mechanisms involved in capsaicin action and to explore the potential therapeuric use of capsaicin in cancer. In the above-mentioned references most of them are dealt with capsaicin—one of the main capsaicinoids, whose general structure is expressed in Figure 1.

Depending on the different chemical structures, such as the length of acyl chain, the absence or presence of double bond and its location along the numbered carbon atom of acyl group, the side methyl group's attachment and its shift to the other numbered carbon atom, and the nature of the substituted groups attached to 3 or 4 positions of benzene ring of the vanillyl group, the capsaicin- 
noids may differ and display greatly in their pungency, probably hence the susceptible curative dose and the finally optimized treatment effect. In present study an attempt was made in an effort to synthesize a series of capsaicinoids, some of which (No. 2, 3 and 7 in Table 1.) had been shown [12-14] to be known-either extracted and separated from the natural pepper or prepared by artificial synthesis from chemical laboratoryes, the others of which are synthesized in our laboratory and characterized to be completely new members of capsaicinoids. The Structure-pungency dependence are presented and discussed.

\section{Experiment}

\subsection{Synthesis}

The synthesis of 2 main intermediates, one is vanillylamine designated as I-1 in Equation (1), the other is corresponding acid chloride designated as I-2 in Equation (1) and used for capsaicinoid-making is conducted in a similar manner as described in our newly approved patent [15] with some modification in choice of appropriate bromine — substituted alkanes as starting raw material by reacting the corresponding acid chlorides (in dry ether) with a suspension of dry vanillylamine in dry ether under an atmosphere of nitrogen as indicated by the following Equation (1) being example for the capsaicin analogues whose molecular have a double bond in the acyl chain.

In case of hydrocapsaicin analogues an unique difference is to use the corresponding saturated fatty acid chloride to replace the unsaturated ones. The structure formula characterized by element analysis. IR. HNMR are listed in Appendix 1.

\subsection{Pungency Determination [16]}

Scoville's sensory assessment method is widely acknowledged domestically and internationally to be used to determine the pungency of capsaicinoid.

The basic principle of this method is based on 1) the first step is to prepare and purify a capsaicinoid (extract or artificial product), 2) an extract or product is weighed accurately (in general $0.050 \mathrm{~g}$ ), 3) To dilute a solution of weighed sample with sucrose aquatic solution continuously and stepwise by multifold to an appropriate ex-

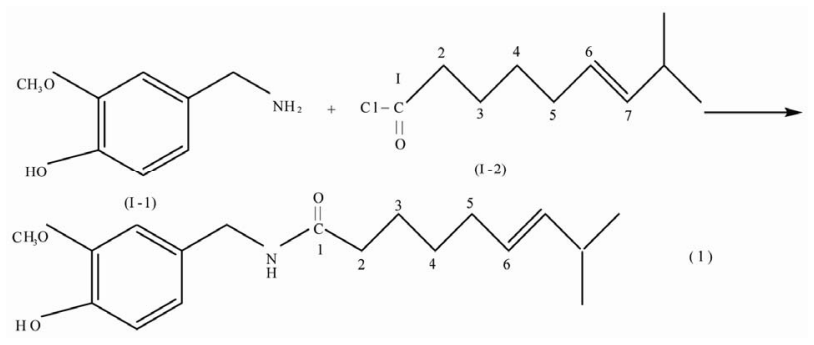

treme degree by which the pungency of a capsaicinoid can be just tasted by sensory organs of individual's group. 4) the experimentally found diluted limit (extreme dilutability) is considered to be scoville Index, expressed as Scoville Heat Unit (simply SHU). The pungency of all the capsaicinoids synthesized in present study are determined in Nutrition and Food Safety Detection Centre of Hunan Agricultural University, Changsha city, Hunan, China.

\section{Results and Discussion}

All the chemical structural formula of capsaicinoids are listed in Table 1. The experimental data needed to characterize individual capsaicinoid such as melting point, elemental analysis HNMR.CNMR, are summarized in Appendix 1. The determined value of capsaicinoid's pungency expressed as SHU are collected in the last column of Table 1 for systematic comparisonas well.

\subsection{Synthesis}

From data listed in Appendix 1, it is shown that the experimentally found data of elemental analysis for each capsaicinoid is coincided with the calculated ones for C.H.N content (\%) within an allowed deviation. HNMR data for each capsaicinoid are in good agreement with the assigned chemical

Shift typical for each functionalized groups contained in new compounds involved. All the above-stated figures tell in flavour that the synthesis of all the members of capsaicinoids we have developed in present study is to be successful.

\subsection{Pungency-Structure Dependence}

A group of systematic and comparative results listed in Table 1 and regarding the pungency-structure dependence, permitted us to reveal the following basic laws governing the heading of pungency alternation.

Firstly among the many factors affecting the pungency of capcaicinoids, the mutuality of hydroxy and methoxy attached to benzene ring of vanilly group have a decisive influence on the pungency, which is clearly demonstrated by comparing the structure and pungency of capsaicinoid No. 10 as one positive side with that of No. 8 and 9 as opposite side. Keeping methoxy group to be unchanged but eliminating the hydroxy (case No. 8) lead to remark= able dropping of the pungency of No.10, leaving only one third of the originol pungency $\left(1.6>0.6 \times 10^{6} \mathrm{SHU}\right)$ alternatively sustaining hydroxy but omitting methoxy enable the pungency continuously dropped to be zero, high lighting the 1-st extreme importance of methoxy and hydroxy mutuality, neither of two groups can be dispensed with, Neither should be overemphasized at the expense to the neglect of the other. The two groups 
Table 1. The Chemical Structural formula Characterized in present study and the pungency (SHU) of capsaicinoids.

\begin{tabular}{|c|c|c|c|}
\hline No. & Structural formula & SHU & reference \\
\hline 1 & & $3 \times 10^{6}$ & ours \\
\hline 2 & Н & $9.1 \times 10^{6}$ & {$[15,16]$} \\
\hline 3 & & $16.1 \pm 0.6 \times 10^{6}$ & {$[15,16]$} \\
\hline 4 & & $12 \times 10^{6}$ & ours \\
\hline 5 & & $0.65 \times 10^{6}$ & ours \\
\hline 6 & $\mathrm{H}$ & $1.1 \times 10^{6}$ & ours \\
\hline 7 & $\mathrm{H}$ & $16.1 \pm 0.6 \times 10^{6}$ & {$[15,16]$} \\
\hline 8 & $\mathrm{H}$ & $0.6 \times 10^{6}$ & ours \\
\hline 9 & $\mathrm{H}$ & $\mathbf{0}$ & ours \\
\hline 10 & & $1.55 \times 10^{6}$ & ours \\
\hline
\end{tabular}


depend on each other for existence, restrict and interact each other to give full play to the pungency functionality.

Secondly, one of the major factors affecting the pungency is the length of acyl chain. Neither too long, for example, chain with more than 9 carbon atoms, nor too short for instance, chain with less than 9 carbon atoms can promote to further upgrade the pungency of capsaicin (case No. 7) and dihydrocapsaicin (case No. 3), whose acyl chain is constituted just from 9 carbon atoms.

Thirdly the methyl group attached to the 8- numbered carbon atom is concluded not to be dispensable, hence might be nonessential or neglectful. Let us have a parallel comparison on the pungency of two members of capsaicinoid, one is norddihydrocapsaicin (case No. 7), whose pungency is $12.1 \pm 0.6 \times 10^{6}$, the other is (E)-N-vanilly(4-hydroxy-3-methoxy benzyl-) nonylamide (case No. 10 ), whose pungency is declined as low as $1.5 \times 10^{6}$ SHU, being one of eighth of the original pungency of capsaicinoid No. 7.

Fourthly It has been known that capsaicin and dihydrocapsaicin differ from each other in the presence(case No. 3) and absence (case No. 7) of double bond at the 8numbered carbon atom, such a structural distinction failed to create a difference in pungency. However it doesn't imply that it is of secondary or even no significance for a factor of double bond. Nothing in chemistry would is invariable. If a double bond's location is shifted and headed for the direction toward the amide planarity, for example, from 6-nonen-(case No. 3) to 4-nonen amide (case No. 4), the pungency value had been lowered from $16.1 \times 10^{6}$ SHU for capsaicinoid No. 3 to $12 \times 10^{6}$ SHU for No. 4.

Finally the effect of Carbon atom number by which the benzene ring and amide plane is separated should also considered to be not ignored, which can be clearly seen when the carbon atom number is increased from one (case No. 10) to two (case No. 5). In response to such a increased carbon atom $\left(-\mathrm{CH}_{2}-\right)$, the pungency is Lessened from $1.5 \times 10^{6}$ (Case 10) to $0.65 \times 10^{6} \mathrm{SHU}$.

\section{Summary}

1) A series of capsaicinoids with different structures have been synthesized and characterized.

2) The pungency of different capsaicinoids has been determined by sensory method expressed as SHU.

3) The pungency is found to be very sensitive and dependent upon the molecular structure alteration occurred within the capsaicinoids.

4) The structure pungency dependence discovered in present study has provided a preliminary basis to further study the structure-curative effect dependence of capsaicinoids with respect to various cancer cells and diseases.

\section{References}

[1] A. Athanasiou, T. E. Bates, et al., "Vanilloid Receptor Agonists and Antagonists Are Mitochon-Drial Inhibitors: How Vanilloids Causenon-Vanilloid Receptor Mediated Cell Death," Biochemcal and Biophysical Research Communications, Vol. 354, No. 1, 2007, pp. 50-55. doi:10.1016/j.bbrc.2006.12.179

[2] A. Mori, S. Lehmann, J. O’kelly et al., "Capsaicin, a Component of Red Peppers, Inhibits the Growth of Andro-Gen-Independent, p53 Mutant Prostate Cancer Cells,” Cancer Research, Vol. 66, No. 6, March 2006, pp. 3222-3229. doi:10.1158/0008-5472.CAN-05-0087

[3] S. Y. Choi, H. Ha and K. T. Kim, "Capsaicin Inhibits Platelet-Activating Factor-Induced Cytosolic $\mathrm{Ca}^{2+}$ Rise and Superoxide Production,” The Journal of Immunology, Vol. 165, No. 7, October 2000, pp. 3992-3998.

[4] D. J. Morre, A. Caldwell, A. Mgyorga, et al., "NADA Oxidase Activity from Sera Altered by Capsaicin Is Widely Distributed among Cancer Patients," Archives of Biochemistry and Biophysics, Vol. 342, No. 2, 1997, pp. 224-230. doi:10.1006/abbi.1997.0110

[5] G. Galati and P. L. O’Brien, “Cytoprotective and Anticancer Properties of Coenzyme Quersus Capsacic,” Biofactors, Vol. 18, No. 1-4, 2003, pp. 195-205. doi:10.1002/biof.5520180222

[6] A. M. Sanchez, J. Martinez-Botas, I. Diaz-Laviada, et al., "Induction of the Endoplasmic Reticulum Stress Protein GADD153/CHOP by Capsaicin in Prostate PC-3 Cell: A Microarray Study,” Biochemical and Bio-Physical Research Communications, Vol. 372, No. 4, 2008, pp. 785791. doi:10.1016/j.bbrc.2008.05.138

[7] S. Malagarie-Cazenave, N. Olea-Herrero, I. Diaz-Laviada, et al., "Capsaicin, a Component of Red Peppers, Induces Expression of Androgen Receptor via PI3K and MAPK Pathways in Prostate LNCaP Cells,” FEBS Letters, Vol. 583, No. 1, 2009, pp. 141-147. doi:10.1016/j.febslet.2008.11.038

[8] I. Diaz-Laviada, "Effect of Capsaicin on Prostate Cancer Cells,” Future Oncology, Vol. 6, No. 10, 2010, pp. 15451550. doi:10.2217/fon. 10.117

[9] A. M. Sanchez, S. Malagarie-Cazenave, I. Diaz-Laviada et al., "Apoptosis Induced by Capsaicin in Prostate PC-3 Cell Involves Ceramide Accumulation, Neutral Sphingomyelinase, and JNK Activation,” Apoptosis, Vol. 12, No. 11, 2007, pp. 2013-2024. doi:10.1007/s10495-007-0119-z

[10] K. C. Brown, T. R. Witte, P. Dasgupta, et al., "Capsaicin Displays Anti-Proliferative Activity against Human Small Cell Lung Cancer in Cell Culture and Nude Mice Models via the E2F Pathway," PloS ONE, Vol. 5, No. 4, 2010, pp. 1-15. doi:10.1371/journal.pone.0010243

[11] K. Ito, T. Nakazato, M. Kizaki, et al., "Induction of Apoptosis in Leukemic Cell by Homovanillic Acid Derivative, Capsaicin, through Oxidative Stress: Implication of Phosphorylation of p52 at Ser-15 Residue by Reactive Oxygen Species," Cancer Research, Vol. 64, 2004, pp. 1071-1078. doi:10.1158/0008-5472.CAN-03-1670 
[12] P. M. Gannett, D. L. Nagel, P. J. Reilly, et al., “The Capsaicinoids: Their Separation, Synthesis, and Mutagenicity," Journal of Organic Chemistry, Vol. 53, No. 5, 1988, pp. 1064-1071. doi:10.1021/jo00261a047

[13] H. Kaga, M. Masakatsu and K. Orito, “A Facile Procedure of Capsaicin,” Journal of Organic Chemistry, Vol. 54, No. 14, 1989, pp. 3477-3478.

doi:10.1021/jo00275a040
[14] S.-Z. Zhou, X.-F. Zhou and B.-X. Peng, “A Novel Synthesis Method of Capsaicinoids," CN-2007100877050.

[15] W. Scoville, "Note on Capsicums," The Journal of the American Pharmacists Association, Vol. 1, No. 5, 1912, pp. 453-454.

[16] D. R. Trainer and A. T. Grenis, "Spices and Seasonings, a Food Technology Handbook,” 2nd Edition, Wiley IEEE, Hoboken, 2001. 


\section{Appendix 1}

\section{Capsaicinoid No. 1}

${ }^{1}$ HNMR of capsaicinoid No. 1 is more complicated than that of capsaicin [8] due to the presence of a unsymmetric carbon atom, HNMR of hydrogen attached to benzene ring is similar to capsaicin [8]. Chemical shift of 3 methy groups is $1.6,1.7$ and $0.96 \mathrm{ppm}$ respectively.

\section{Capsaicinoid No. 2}

All the ${ }^{1} \mathrm{HNMR}$ data are totally coincided with that of nordcapsaicin in paper [8].

\section{Capsaicinoid No. 3}

All the ${ }^{1} \mathrm{HNMR}$ data are totally coincided with that of capsaicin in paper [8].

\section{Capsaicinoid No. 4}

Elementary analysis (\%) Calculated: C, 70.79; H, 8.91; N, 4.59. Found: C, 70.84; H, 9.06; N, 4.41.

${ }^{1} \mathrm{HNMR}(\mathrm{CDCl} 3) \delta(\mathrm{ppm}): 0.856\left(6 \mathrm{H}, \mathrm{CH}_{3}\right), 1.183$ $\left(2 \mathrm{H}, \mathrm{CH}_{2}\right), 1.514(1 \mathrm{H}, \mathrm{CH}), 1.953\left(2 \mathrm{H}, \mathrm{C}=\mathrm{C}-\mathrm{CH}_{2}\right), 2.254$ $\left(2 \mathrm{H}, \mathrm{O}=\mathrm{C}-\mathrm{CH}_{2}\right), 2.341\left(2 \mathrm{H}, \mathrm{CH}_{2}-\mathrm{C}=\mathrm{C}\right), 3.884(3 \mathrm{H}$, $\left.\mathrm{OCH}_{3}\right), 4.351\left(2 \mathrm{H}, \mathrm{ArCH}_{2}\right), 5.428(2 \mathrm{H}, \mathrm{CH}=\mathrm{CH}), 5.579$ $(1 \mathrm{H}, \mathrm{OH}), 5.673(1 \mathrm{H}, \mathrm{NH}), 6.763(1 \mathrm{H}, 6-\mathrm{ArH}), 6.808$ (1H, 2-ArH), 6.864 (1H, 5-ArH).

DEPT $135^{\circ} \delta$ (ppm): $22.493\left(+, \mathrm{CH}_{3}\right), 27.494(+, \mathrm{CH})$, $28.663\left(-, \mathrm{CH}_{2}\right), 30.379\left(-, \mathrm{CH}_{2}\right), 36.719$ (-, $\left.\mathrm{CH}_{2}\right)$, $38.619\left(-, \mathrm{CH}_{2}\right), 43.565\left(-, \mathrm{CH}_{2}\right), 55.954$ (+, $\left.\mathrm{OCH}_{3}\right)$, $110.708(+, \mathrm{CH}), 114.362(+, \mathrm{CH}), 120.835(+, \mathrm{CH})$, $127.985(+, \mathrm{CH}), 132.306(+, \mathrm{CH})$.

\section{Capsaicinoid No. 5}

Elementary analysis (\%) Calculated: C, 70.32; H, 9.51; N, 4.56. Found: C, 70.69; H, 9.41; N, 4.68.

${ }^{1} \mathrm{HNMR}\left(\mathrm{CDCl}_{3}\right) \delta(\mathrm{ppm}): 0.876\left(3 \mathrm{H}, \mathrm{t},-\mathrm{CH}_{3}\right), 1.1 \sim$ $1.4\left(10 \mathrm{H},-\left(\mathrm{CH}_{2}\right)_{5}-\mathrm{Me}\right), 1.588\left(2 \mathrm{H}, \mathrm{m},-\mathrm{CH}_{2}-\right), 2.121(2 \mathrm{H}$, t, $\left.\mathrm{CO}-\mathrm{CH}_{2-}\right), 2.743\left(2 \mathrm{H}, \mathrm{t}, \mathrm{Ar}-\mathrm{CH}_{2^{-}}\right), 3.489$ (2H, q,

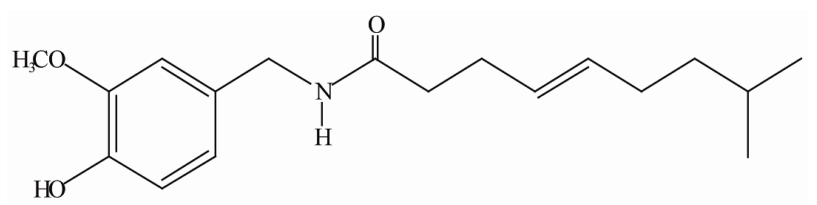

N-[2-(4-hydroxy-3-methoxybenzyl)]-8-methyl-4-nonenamide

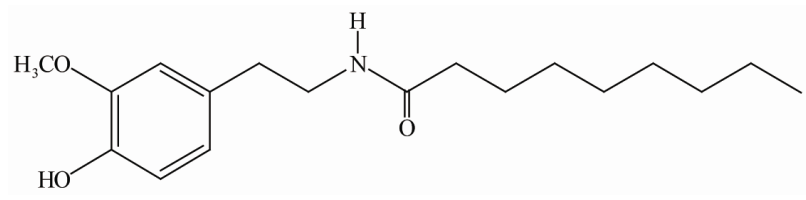

$\mathrm{N}$-[2-(4-hydroxy-3-methoxyphenyl)ethyl]nonanamide<smiles>CCCCCCCCC(=O)NCc1ccc(OC)c(OC)c1</smiles>

N-(3,4-dimethoxybenzyl)nonanamide<smiles>CCCCCCCCC(=O)NCc1cccc(OC)c1</smiles>

N-(3-methoxybenzyl) nonanamide<smiles>CCCCCCCCC(=O)NCc1ccc(O)cc1</smiles>

N-(4-hydroxybenzyl) nonanamide

$\left.-\mathrm{CH}_{2}-\mathrm{N}\right), 3.880$ (3H, s, Ar- $\mathrm{OCH}_{3}$ ), 5.430 (2H, s, -NH-CO, Ar-OH), $6.665 \sim 6.860$ (3H, Ar-H).

DEPT $135^{\circ}\left(\mathrm{CDCl}_{3}\right) \delta(\mathrm{ppm}): 14.094\left(+, \mathrm{CH}_{3}\right), 22.646$ $\left(-, \mathrm{CH}_{2}\right), 25.795\left(-, \mathrm{CH}_{2}\right), 29.144\left(-, \mathrm{CH}_{2}\right), 29.297$ (-, $\left.\mathrm{CH}_{2}\right)$, $29.321\left(-, \mathrm{CH}_{2}\right), 31.827\left(-, \mathrm{CH}_{2}\right), 35.399$ (-, $\left.\mathrm{CH}_{2}\right)$, $36.905\left(-, \mathrm{CH}_{2}\right), 40.672\left(-, \mathrm{CH}_{2}\right), 55.916\left(+, \mathrm{OCH}_{3}\right)$.

\section{Capsaicinoid No. 6}

Elementary analysis (\%) Calculated: C, 70.32; H, 9.51; N, 4.56. Found: C, 69.93; H, 9.59; N, 4.57.

${ }^{1} \mathrm{HNMR}\left(\mathrm{CDCl}_{3}\right) \delta(\mathrm{ppm}): 0.880\left(3 \mathrm{H}, \mathrm{t},-\mathrm{CH}_{3}\right), 1.1 \sim$ $1.4\left(10 \mathrm{H},-\left(\mathrm{CH}_{2}\right)_{5}-\mathrm{Me}\right), 1.656\left(2 \mathrm{H}, \mathrm{m},-\mathrm{CH}_{2}-\right), 2.207(2 \mathrm{H}$, t, $\left.\mathrm{CO}-\mathrm{CH}_{2}-\right), 3.071\left(6 \mathrm{H}, \mathrm{s}, 2 \mathrm{Ar}-\mathrm{OCH}_{3}\right), 4.377(2 \mathrm{H}, \mathrm{d}$, Ar- $\left.\mathrm{CH}_{2}-\right)$, 5.736 (1H, s, -NH-CO), 6.820 (3H, s, Ar-H).

DEPT $135^{\circ}\left(\mathrm{CDCl}_{3}\right) \delta(\mathrm{ppm}): 14.069\left(+, \mathrm{CH}_{3}\right), 22.630$ (-, $\left.\mathrm{CH}_{2}\right), 25.804\left(-, \mathrm{CH}_{2}\right), 29.148\left(-, \mathrm{CH}_{2}\right), 29.319$ (-, $\left.\mathrm{CH}_{2}\right), 31.805\left(-, \mathrm{CH}_{2}\right), 36.852\left(-, \mathrm{CH}_{2}\right), 43.426\left(-, \mathrm{CH}_{2}\right)$, $55.885\left(+, \mathrm{OCH}_{3}\right), 55.953\left(+, \mathrm{OCH}_{3}\right)$.

\section{Capsaicinoid No. 7}

All the ${ }^{1}$ HNMR data are totally coincided with that of dihydrocapsaicin in paper [8].

\section{Capsaicinoid No. 8}

Elementary analysis (\%) Calculated: C, 73.61; H, 9.81; N, 5.05. Found: C, 73.75; H, 9.93; N, 5.13.

${ }^{1} \mathrm{HNMR}\left(\mathrm{CDCl}_{3}\right) \delta(\mathrm{ppm}): 0.876\left(3 \mathrm{H}, \mathrm{t},-\mathrm{CH}_{3}\right), 1.1 \sim$ $1.4\left(10 \mathrm{H},-\left(\mathrm{CH}_{2}\right)_{5}-\mathrm{Me}\right), 1.655\left(2 \mathrm{H}, \mathrm{m},-\mathrm{CH}_{2}-\right), 2.210(2 \mathrm{H}$, t, $\left.\mathrm{CO}-\mathrm{CH}_{2}-\right), 3.796\left(3 \mathrm{H}, \mathrm{s}, \mathrm{Ar}-\mathrm{OCH}_{3}\right), 4.415(2 \mathrm{H}, \mathrm{d}$, Ar- $\left.\left.\mathrm{CH}_{2}\right)^{-}\right), 5.727$ (1H, s, -NH-CO), $6.809 \sim 7.243(4 \mathrm{H}$, Ar-H).

DEPT $135^{\circ}\left(\mathrm{CDCl}_{3}\right) \delta(\mathrm{ppm}): 14.077\left(+, \mathrm{CH}_{3}\right), 22.638$ $\left(-, \mathrm{CH}_{2}\right), 25.787\left(-, \mathrm{CH}_{2}\right), 29.148\left(-, \mathrm{CH}_{2}\right), 29.309$ (-, 
$\left.\mathrm{CH}_{2}\right), 29.328\left(-, \mathrm{CH}_{2}\right), 31.807\left(-, \mathrm{CH}_{2}\right), 36.832\left(-, \mathrm{CH}_{2}\right)$, $43.557\left(-, \mathrm{CH}_{2}\right), 55.232\left(+, \mathrm{OCH}_{3}\right)$.

\section{Capsaicinoid No. 9}

Elementary analysis (\%) Calculated: C, 72.97; H, 9.57; N, 5.32. Found: C; H; N.

${ }^{1} \mathrm{HNMR}\left(\mathrm{CDCl}_{3}\right) \delta(\mathrm{ppm}): 0.876\left(3 \mathrm{H}, \mathrm{t},-\mathrm{CH}_{3}\right), 1.1 \sim$ $1.4\left(10 \mathrm{H},-\left(\mathrm{CH}_{2}\right)_{5}-\mathrm{Me}\right), 1.646\left(2 \mathrm{H}, \mathrm{m},-\mathrm{CH}_{2}-\right), 2.202(2 \mathrm{H}$, t, $\left.\mathrm{CO}-\mathrm{CH}_{2}^{-}\right), 4.359$ (2H, d, $\left.\mathrm{Ar}-\mathrm{CH}_{2}^{-}\right)$.
DEPT $135^{\circ}\left(\mathrm{CDCl}_{3}\right) \delta(\mathrm{ppm}): 14.081\left(+, \mathrm{CH}_{3}\right), 22.629$ $\left(-, \mathrm{CH}_{2}\right), 25.774\left(-, \mathrm{CH}_{2}\right), 29.127\left(-, \mathrm{CH}_{2}\right), 29.258$ (-, $\left.\mathrm{CH}_{2}\right), 29.273\left(-, \mathrm{CH}_{2}\right), 31.794\left(-, \mathrm{CH}_{2}\right), 36.856\left(-, \mathrm{CH}_{2}\right)$, $43.268\left(-, \mathrm{CH}_{2}\right)$.

\section{Capsaicinoid No. 10}

Except methyl group at 8-numbered carbon atom for No.7 all the ${ }^{1}$ HNMR data are totally coincided with that of dihydrocapsaicin in paper [8]. 